\title{
Group Communication Support in Supporting the Resilience of Families and Survivors of Covid-19
}

\section{Dukungan Komunikasi Kelompok Dalam Menunjang Ketahanan Keluarga Dan Penyintas Covid-19}

\author{
Rose Emmaria Tarigan ${ }^{1}$ \\ ${ }^{1}$ Universitas Pelita Harapan, Prodi Ilmu Komunikasi, Jl. M. H. Thamrin Boulevard 1100 Lippo \\ Village Tangerang 15811 - Indonesia* \\ Email: rose.tarigan@uph.edu
}

Masuk tanggal : 06-03-2021, revisi tanggal :09-06-2021, diterima untuk diterbitkan tanggal : 10-06-2021

\begin{abstract}
The Covid-19 pandemic originating from Wuhan has caused a lot of problems in people's life aside from the economic costs. The Covid-19 has also taken its toll in almost every country in the world. Millions have died. Families need communication supports to face Covid-19. Group communication support has a very important role in sustaining the Covid-19 survivors and their families. To understand how it can sustain the Covid-19 survivors and their families, the researcher used the case-study approach and collected data through in-depth interviews with three respondents and analyzed them. This study aims to find out how the role of group communication support for survivors in supporting their resilience against Covid-19. The result shows that group communication supports link with five skills in designing supportive messages, i.e.: clarifying supportive intentions, buffering face threats, using other-centered messages, framing messages, and giving advice. These five skills provide a positive influence to the survivors and their families. The support messages have helped them go through difficult times caused by Covid-19. The research also found other sustaining aspects: the ability of the three respondents to see the calamities positively according to their religions and their strong personalities. Their personalities have enabled them to show positive attitudes to their children. In turn, their children also have the same resolute, strong, and resilient attitude in facing their calamities.
\end{abstract}

Keywords: communication supports, community, Covid-19 survivors and families sustainability, supportive message

\begin{abstract}
Abstrak
Pandemi Covid-19 yang berasal dari Wuhan, telah menimbulkan banyak masalah bagi kehidupan manusia, tidak hanya kerugian secara ekonomi saja. Covid-19 juga telah merenggut banyak nyawa manusia hampir di semua belahan dunia. Jutaan nyawa melayang dan jutaan keluarga membutuhkan adanya dukungan komunikasi sebagai akibat serangan Covid-19 ini. Dukungan komunikasi kelompok memiliki peranan yang sangat penting guna menunjang ketahanan dari keluarga dan juga penyintas Covid-19 ini. Untuk mengetahui bagaimana dukungan komunikasi kelompok bisa menunjang ketahanan keluarga dan penyintas Covid-19, maka dilakukan penelitian dengan pendekatan studi kasus, yakni mengumpulkan data melalui wawancara mendalam kepada tiga informan dan selanjutnya menganalisisnya. Penelitian ini bertujuan untuk
\end{abstract}


menemukan bagaimana peranan dukungan komunikasi kelompok terhadap penyintas dalam menunjang ketahanan mereka menghadapi Covid-19. Hasil penelitian ini menunjukkan bahwa, dukungan komunikasi dari kelompok terkait dengan lima kemampuan mengemas pesan yang mendukung (support message), antara lain; clarify supportive intentions, buffering face threats, other centered message, framing, giving advice. Kelima keterampilan ini memberi pengaruh yang positif, kepada keluarga dan korban Covid-19. Adanya support message ini, membuat keluarga dan penyintas Covid19 mampu melewati masa sulit sebagai akibat dari Covid-19 ini. Penelitian ini juga menemukan, bahwa terdapat aspek lainnya yakni, kemampuan yang dimiliki ketiga informan untuk melihat musibah yang mereka alami secara positif sesuai dengan ajaran agama yang mereka yakini, dan juga kekuatan kepribadian mereka yang tangguh. Kepribadian yang kuat, yang mereka miliki membuat mereka berhasil menunjukkan sikap positif kepada anak-anak mereka. Sebagai akibatnya, anak-anak merekapun memiliki sikap yang sama yakni tegar, kuat, tabah menjalani musibah yang mereka alami.

Kata Kunci: dukungan komunikasi, ketahanan keluarga dan penyintas Covid-19, komunitas, pesan pendukung

\section{Pendahuluan}

Penyebaran virus Covid-19 sangat cepat dan dampaknyapun mematikan bagi mereka yang terkena, khususnya yang berusia lanjut dan berpenyakit penyerta (komorbid). Dunia gempar disebabkan dampak yang ditimbulkan dari kehadiran Covid-19 yang berasal dari Kota Wuhan, dan pada awal kemunculannya telah melumpuhkan perekonomian dunia. Tidak ada satu Negara yang aman dari Covid-19 ini, meskipun ada perbedaan masing-masing negara dalam penanganannya. Negara seperti Taiwan, Singapura, Korea Selatan dianggap lebih cepat dan mampu mengatasinya meskipun mereka tetap melakukan pengawasan yang ketat atas penyebaran Covid-19 ini. (Mukaromah, 2020)

Pemerintah mengharapkan sejak ditemukannya di awal bulan Maret, maka puncak penyebaran dari Covid -19 ini akan mengalami penurunan (curva melandai) pada akhir bulan April. Tetapi kenyataanya yang terjadi adalah prediksi tersebut melenceng dari perkiraan awal. Bahkan hingga empat bulan setelah bulan Maret peningkatan jumlah korban Covid-19 terus bertambah, pertanggal data terbaru perkembangan kasus Virus Corona atau Covid-19 pada Kamis (2/7) pukul 12.00 WIB menunjukkan, jumlah pasien yang dinyatakan positif bertambah 1.624 orang. Sehingga total menjadi 59.394 kasus positif Covid-19. Sementara untuk pasien sembuh bertambah 1.072 orang. Total kasus sembuh secara akumulatif sebanyak 26.667 orang. Kasus meninggal pertanggal 2 Juni 2020, bertambah 53 orang. Sehingga total pasien yang meninggal menjadi 2.987 orang. (Indah, 2020).

Penanganan pasien korban Covid-19 pun terbilang unik. Apabila korban Covid-19 kemudian meninggal maka segera dalam waktu empat jam harus segera dikebumikan, tanpa menyertakan keluarga pihak korban dalam semua prosesnya. Situasi seperti ini pasti sungguh sangat menyedihkan dan membuat para keluarga penyintas dan penyintas Covid-19 ini akan sangat memerlukan dukungan dari orang-orang sekitarnya yang dapat meringankan beban yang mereka harus 
Rose Emmaria Tarigan:

Group Communication Support in Supporting the Resilience of Families and Survivors of Covid19

Dukungan Komunikasi Kelompok Dalam Menunjang Ketahanan Keluarga Dan Penyintas Covid19

tanggung. Dalam situasi seperti ini, maka kehadiran keluarga, sahabat, rekan kerja, komunitas akan sangat diperlukan karena dapat memberi dampak yang positif kepada keluarga dan penyintas Covid-19 itu sendiri. Hal ini seperti yang dialami oleh tiga informan dalam penelitian ini. Kedua penyintas ini berjenis kelamin perempuan dan satu di antara mereka adalah keluarga penyintas

Kedua penyintas Covid 19 dan juga sebagai keluarga korban mengalami masa-masa yang berat selama dalam proses karantina. Situasi yang serba tidak pasti, karena belum ada obat atau anti virus yang bisa memberikan ketenangan batin mereka. Mereka yang sebelumnya berada dalam kondisi sehat, dinyatakan harus menjalani sejumlah tes dan karantina. Selain itu sebagai seorang ibu, mereka juga harus memikir anak-anak mereka yang masih membutuhkan perhatian, karena beberapa di antaranya masih dalam usia sekolah. Di tengah kondisi yang mereka alami ini, perhatian dan dukungan dari keluarga dan komunitas di mana mereka aktif berorganisasi seperti gereja dan persekutuan, membuat mereka mendapatkan dukungan yang mereka butuhkan. Antara lain, dukungan memenuhi kebutuhan mereka, seperti; dukungan emosi, informasi, konkrit, dan juga dukungan jaringan sosial. Terpenuhinya kebutuhan ini, membuat ketiga informan mampu lepas dari tekanan psikologis seperti stres dan depresi, yang sangat mungkin dialami oleh korban Covid-19 ini.

Penelitian ini bertujuan mengetahui bagaimana dukungan sosial dari lingkungan dapat mendukung ketahanan keluarga dan penyintas Covid-19 dari beragam tekanan. Sebagaimana sudah dibuktikan dalam sebuah kajian yang dilakukan kepada sejumlah pasien dengan gejala ringan penyakit corona virus 2019 (COVID-19) di Wuhan, Cina. Dari hasil penelitian direkomendasikan bahwa dukungan sosial menjadi salah satu faktor yang dapat mendukung ketahanan dari korban Covid-19 ini. Secara ringkas, status psikologis sebagian besar pasien dengan gejala COVID-19 ringan adalah normal dan ketahanan antar pasien relatif tinggi dibandingkan dengan pasien lain dalam penelitian ini. Pasien dengan gejala COVID-19 ringan yang memiliki tingkat ketahanan yang lebih tinggi dapat mengalami tingkat kecemasan dan depresi yang lebih rendah, sehingga menjadikan ketahanan sebagai faktor pelindung karena membantu pasien melawan emosi negatif. Oleh karena itu, meningkatkan tingkat ketahanan pasien dapat bermanfaat untuk pencegahan stres psikologis dan dapat berkontribusi pada peningkatan kesehatan mental, terutama dalam hal kecemasan dan depresi. (Zhang, RN Jie, et.al 2020)

Seperti yang ditemukan juga bahawa dukungan komunikasi kelompok memang memiliki peranan yang besar dalam membebaskan seseorang dari tekanan sebagai akibat dari masalah atau peristiwa yang mereka alami. Seperti dalam penelitian yang dilakukan oleh Sepfitri tentang adanya Pengaruh Dukungan Sosial terhadap Motivasi Berprestasi Siswa SMAN 6 Jakarta. Penelitian ini menemukan bahwa dukungan sosial yang meliputi, dukungan penghargaan, dukungan instrumental, dukungan informasi dan dukungan jaringan yang diberikan berpengaruh terhadap motivasi berprestasi dari Siswa SMAN 6 Jakarta (Netta, 2011). Apa yang dialami oleh para perawat dan pelajar atau siswa yang sama dalam kondisinya mengalami tekanan dari lingkungan kerja dan sekolah membuat adanya dukungan sosial menjadi sangat penting untuk mengurangi 
tekanan dalam bekerja dan belajar. Dukungan sosial ini tidak terbatas hanya kepada teman yang kita kenal secara offline saja, karena juga bisa mendapatkan dukungan sosial dari teman lewat media sosial seperti Facebook. Sebagaimana hasil survey yang menemukan ada seorang korban Covid-19, Jessica Stapleton, yang bergabung di Facebook di bulan Maret pada awalnya grup ini hanya memiliki 800 anggota yang kemudian berkembang menjadi 18.000 orang. Di dalam grup ini mereka yang menjadi korban Covid-19 mendapatkan dukungan sosial dari anggota grup facebook tersebut. Mereka tidak lagi merasa sendiri karena mereka dapat berbagi dengan orang lain yang mengalami hal sama di dalam group, jadi bisa saling menguatkan, jadi dukungan sosial bisa juga dari sesama korban (Team, 2020).

Penelitian ini akan mengkaji bagaimana peranan dukungan sosial bagi ketahanan keluarga dan korban Covid-19 dalam mengatasi masalah yang mereka hadapi. Penelitian ini adalah satu kajian terkait dengan masalah dukungan kelompok terhadap anggota komunitasnya yang mengalami musibah. Dukungan kelompok termasuk juga sebagai dukungan sosial memiliki peranan yang sangat penting bagi keluarga dan para penyintas. Penelitian ini juga akan melihat bagaimana ukungan kelompok dan penelitian ini fokus kepada dukungan pesan (supporting message), menjadi penting karena berperan dalam mendukung ketahanan korban atau penyintas terkait satu peristiwa atau masalah tertentu. Untuk itu penting memahami pertama dari sisi manusianya. Manusia menjadi sangat unik, ketika menghadapi situasi sulit maka di dalam dirinya terdapat kemampuan untuk mengatasi situasi apapun yang dihadapinya. Untuk memenuhi kebutuhannya manusia tidak dapat lepas dari yang namanya kelompok, atau manusia lainnya yang disebut dengan kelompok sosial. Kelompok sosial adalah kelompok yang terdiri dari dua atau lebih orang yang mengindentifikasi, dan berinteraksi satu sama lain (Macionis, 2008). Melalui kelompok, seseorang dapat memenuhi beragam kebutuhannya mulai dari, kebutuhan biologis, kebutuhan keamanan, kebutuhan hubungan sosial, kebutuhan penghargaan diri dan aktualisasi diri. Kelompok ini seperti pasangan, teman kerja, satu gereja, rekan bisnis, teman sekolah dan lain-lain. Untuk memenuhi kebutuhannya ini maka manusia berelasi dengan manusia lainnya. Terkait peran kelompok, dari hasil penelitian terkait korban kebakaran di California, yang biasanya sangat memungkinkan mendapatkan gangguan pada kesehatan mental mereka (mental health), ternyata dengan adanya dukungan kelompok atau sosial yang tinggi dapat membuat mereka lebih baik ketika ada stressor hidup dibandingkan dengan dukungan sosial rata-rata atau rendah (Felix D, E \& Avivi, 2015)

Pada dasarnya manusia memiliki dua jenis kelompok, yang disebut dengan kelompok primer dan sekunder. Kelompok primer adalah kelompok sosial yang kecil, di mana anggotanya membagi hubungan personal dan dalam waktu yang lama. Kelompok sekunder adalah kelompok yang besar dan bersifat tidak personal yang anggota kelompoknya berusaha untuk mencapai tujuan khusus atau aktivitas tertentu. Dalam prakteknya kedua kelompok ini hadir dalam hidup seseorang dan kedua jenis kelompok ini memiliki perannya sendiri dalam memenuhi kebutuhan dari anggota kelompoknya. Sedangkan menurut Sarlito, kelompok itu memiliki batasan, yakni adalah dua individu atau lebih yang berinteraksi tatap muka (face 
Rose Emmaria Tarigan:

Group Communication Support in Supporting the Resilience of Families and Survivors of Covid19

Dukungan Komunikasi Kelompok Dalam Menunjang Ketahanan Keluarga Dan Penyintas Covid19

to face interaction), yang masing-masing menyadari keanggotaannya dalam kelompok, masing-masing menyadari keberadaan orang lain yang juga anggota kelompok, dan masing-masing menyadari saling ketergantungan secara positif dalam mencapai tujuan yang bersama. (Sarlito, Wirawan, 2005). Kelompok adalah sejumlah orang yang bukan bersifat kerumunan tetapi terdiri dari dua, tiga atau lebih yang saling berinteraksi, bersifat interdependen (saling tergantung), memiliki sebuah tujuan, dan aturan yang mereka ikuti bersama (Wood, T, 2011). Di dalam kelompok biasanya ada aturan yang tidak tertulis yang harus diikuti oleh anggota kelompok. Salah satunya adalah kepedulian satu terhadap yang lain, misalnya kalau terjadi masalah yang menimpa satu anggota maka anggota lainnya akan memberikan perhatian atau kepedulian kepada anggota yang mengalaminya. Dapat disimpulkan, bahwa kelompok memiliki peranan penting bagi setiap individu yang menjadi bagian dari satu kelompok dan semakin mempertegas bahwa manusia itu adalah makhluk sosial yang membutuhkan kehadiran orang lain dalam hidupnya. Kelompok dibutuhkan bisa memberi dukungan ketika anggota mengalami permasalahan, dan membutuhkan bantuan.

Sebagaimana penelitian Jones, 2004 dukungan komunikasi kelompok akan memberikan dampak yang positif kepada mereka yang mengalami masalah atau musibah. Demikian juga dukungan yang efektif, akan mengurangi kesulitan dan membantu untuk mengatasinya. Dukungan komunikasi menurut Bureleson: "Supportive communication as verbal and nonverbal behavior produced with the intention of providing assistance to others is a fundamental form of human communication"(Burleson R Brant, 2002). Ini menunjukkan bahwa komunikasi yang mendukung, sebagai perilaku verbal dan nonverbal yang dihasilkan dengan maksud memberikan bantuan kepada orang lain, adalah bentuk dasar komunikasi manusia.

Dukungan komunikasi menjadi sangat fundamental bagi kelompok, khususnya bagi anggota dari sebuah kelompok mengalami masalah, atau kesulitan yang membuat seseorang atau kelompok membutuhkan bantuan atau dukungan dari anggota lainnya. Sejumlah penelitian menunjukkan bahwa dukungan dari kelompok menghasilkan dampak yang positif bagi mereka yang didukung. Antara lain, penelitian dari Krause, Liang \& Yatomi, 1989; Lackner et al.,1993, di mana dukungan yang efektif telah menumbuhkan penyesuaian psikologis dan self efficacy yang artinya, keyakinan seseorang bahwa ia memiliki kemampuan melakukan sesuatu untuk mencapai tujuannya (Burleson R Brant, 2002). Demikian juga dengan penelitian dari Pierce, Sarason, \& Sarasons, 1996;Tardy,1994), menyatakan bahwa dukungan kelompok dapat meningkatkan kemampuan dalam mengatasi masalah yang mengganggu (Burleson R Brant, 2002). Dalam penelitian Burleson, 2002, lainnya ditemukan, bahwa dukungan komunikasi tidak hanya berkontribusi kepada teori dari formasi dan pengembangan hubungan pribadi, tetapi juga kepada karakter moral. Dijelaskan bahwa "Supportive communication frequently displays the highest expressions of the human spirit, so by studying this behavior we better acquaint ourselves with the nature and practice of virtue in everyday life". Komunikasi suportif sering menampilkan ekspresi tertinggi dari roh manusia, jadi dengan mempelajari 
perilaku ini, lebih baik kita mengenal diri sendiri dengan sifat dan praktik kebajikan dalam kehidupan sehari-hari.

Ada beberapa istilah yang berkaitan dengan konsep dukungan komunikasi ini, antara lain dukungan sosial, dukungan interaktif dan semua konsep ini berasal dari dua pendekatan, yakni pendekatan psikologis dan juga sosiologis, sebagaimana dikemukakan oleh Burleson dan Albrecht, Goldsmith, \& Sarason, 1994. Mereka mengatakan bahwa komunikasi juga layak mendapat tempat yang jauh lebih sentral dalam studi dukungan sosial. Mereka percaya bahwa dukungan sosial harus dipelajari sebagai komunikasi, karena pada akhirnya disampaikan melalui pesan yang diarahkan oleh satu orang ke orang lain, dalam konteks hubungan yang dibuat dan dipertahankan melalui interaksi (Burleson R Brant, 2002). Komunikasi dalam hal ini, dukungan pesan (supportive messages) menjadi fokus atau sentral dari penelitian tentang dukungan sosial (social Support). Burleson, 1987 mengatakan bahwa supportive messages memiliki tujuan untuk melepaskan emosi-emosi yang sulit, bentuk danisi dari supportive messages lebih kepada emosi daripada fokus kepada masalah. Dukungan pesan yang fokus kepada emosi memenuhi dua fungsi, antara lain: 1) mengungkapkan kepedulian dan belas kasihan, 2) membantu untuk melepaskan emosi-emosi negatif. (Jones, M, Susane \& Bodie, D, 2014).

Selain itu, dukungan komunikasi dari kelompok akan membuat atau menambah daya tahan atau ketahanan penyintas atau orang yang memerlukan dukungan dalam menghadapi masalah ataupun musibah. Demikian pula dengan pesan-pesan dukungan (supportive messages) ini, akan dianggap sebagai penting dari perilaku komunikatif tertentu, oleh satu pihak dengan tujuan memberi manfaat atau membantu pihak lain. Dengan demikian, pesan yang mendukung hanyalah satu bagian dari "interaksi yang mendukung," yang terakhir dapat dipahami sebagai urutan percakapan yang lebih luas atau episode yang juga termasuk mencari, menerima, memproses, dan menanggapi upaya dukungan. Supporting messages tidak bisa dipisahkan dengan comforting messages yang berhubungan dengan emotional support. The comforting messages are efforts to reassure, bolster, encourage, soothe, console and cheer up. In this section we label all these efforts as supporting. Pesan-pesan yang menghibur adalah upaya untuk meyakinkan, mendukung, menyemangati, menenangkan, menghibur. Di bagian ini, kemudian diberi label bahwa semua upaya ini sebagai pendukung, (Verderber, S Kathleen; Verderber, F Rudolph; Fink-Berryman, 2007). Supporting juga dikembangkan menjadi supporting respons adalah sebuah pernyataan yang tujuannya adalah untuk menunjukkan persetujuan, untuk meyakinkan, mendukung, menyemangati, menenangkan, menghibur dan menghibur. Dalam hal bentuk supportive ada dua yakni, supporting (approving) positive feelings, dan negative feeling. Supporting positive feeling, biasanya menghargai perasaan ketika membagikannya kepada orang lain, individu tidak ingin orang lain atau pendengar memutusnya dengan tanggapan yang tidak sesuai dengan apa yang dimaksudkannya. Pada dasarnya supportive positive feeling secara umum mudah, tetapi membutuhkan perhatian atau kepedulian. Supportive negative feeling, adalah ketika seseorang mengalami situasi yang tidak menyenangkan, untuk itu sangat dibutuhkan pernyataan dukungan yang efektif. 
Rose Emmaria Tarigan:

Group Communication Support in Supporting the Resilience of Families and Survivors of Covid19

Dukungan Komunikasi Kelompok Dalam Menunjang Ketahanan Keluarga Dan Penyintas Covid19

Dengan mengetahui kondisi perasaan seseorang maka seseorang dapat membantu orang lain yang membutuhkannya.

Barbee dan Cunningham (1955), mengidentifikasi empat fase yang tertata dengan baik sehingga interaksi yang mendukung tampaknya terus berlanjut, antara lain, Fase pertama, adalah support activation, fase kedua support provision, fase ketiga target reaction, dan fase empat adalah helper responses. Burlesson mengidentifikasi adanya lima keterampilan, mengemas pesan yang mendukung (support message), antara lain; clarify supportive intentions, buffering face threats, other centered message, framing, giving advice, kelima keterampilan ini akan menjelaskan bagaimana pelaku melakukan dukungan komunikasi terhadap anggota kelompok mereka yang mengalami masalah, musibah atau tekanan (Burleson R Brant, 2002).

Clarifying supportive intention, adalah "openly state that our goal in the conversation to support and help our partner". Artinya bahwa, seseorang menyatakan pesan komunikasinya, secara terbuka dan tujuannya dalam percakapan adalah untuk mendukung dan membantu pasangannya. Ketika seseorang berkomunikasi secara terbuka, maka orang lain akan melihat dan bisa merasakan apakah memiliki agenda tersembunyi atau tidak. Dengan demikian maka pesan komunikasi akan efektif, jika terbebas dari beragam motif atau agenda terselubung. Biasanya untuk terhindar dari kecurigaan lawan bicara, maka ada baiknya melakukannya 1) secara langsung mengungkapkan tujuan dengan menekankan niat atau keinginan untuk menolong, 2) ingatkan teman atau orang lain atas adanya komitmen dari hubungan atau relasi mereka, 3) tunjukkan bahwa menolong adalah tujuan satu-satunya motif yang dimiliki, 4) dan frasekan kejernihanmu dengan cara merefleksikan kegunaannya.

Buffering face threats, anda mungkin menemukan bahwa tindakan memberikan dukungan emosional dapat mengancam kebutuhan wajah pasangan Anda, oleh karena itu maka akan lebih baik jika pelaku komunikasi menggunakan positive facework, yakni berupa pesan yang memproteksi kebutuhan lawan bicara sulit. Ini berbeda dengan negative facework, pesan yang mendukung kebutuhan mitra akan kemandirian dan otonomi secara verbal menggunakan metode tidak langsung ketika menawarkan informasi, pendapat, saran, mereka. Positive facework dapat dilakukan dengan cara 1) gambarkan dan temukan perasaan yang positif atas apa yang orang lain katakan dan lakukan dalam satu situasi, 2) ungkapkan penghargaanmu atas keberanian dan usaha seseorang dalam situasi tertentu. 3) ketahuilah berapa sulit situasi saat itu, 4) ungkapkan keyakinanmu bahwa orang lain memiliki kualitas untuk menanggung masalah atau berhasil. Negative facework dilakukan dengan cara, 1) mintalah ijin sebelum membuat saran atau nasehat, 2) secara verbal menunda untuk memberikan opini atau preferensi ke orang lain, 3) gunakan bahasa yang bersifat tentatif, dalam memberikan nasehat dan opini, 4) menawarkan sara secara tidak langsung dengan cara menggungkapkan kisah atau menggambarkan pilihan hipotesis. Other centered messages, adalah mendengarkan secara aktif, mengungkapkan belas kasih dan pengertian, dan mendorong mitra untuk berbicara tentang apa yang telah terjadi, menguraikannya, dan mengeksplorasi perasaan mereka tentang situasi tersebut. Framing, keterampilan memberikan kenyamanan dengan 
menawarkan informasi, pengamatan, dan pendapat yang memungkinkan pengungkap untuk lebih memahami atau menafsirkan kembali suatu peristiwa atau keadaan. Statemen yang kita framing akan terlihat supportive atau mendukung partner kita, jika mereka dapat menenangkan perasaan mereka dengan menolong mereka, melihat apa yang terjadi pada diri mereka tanpa menyinggung harga diri mereka. Jenis pesannya antara lain; 1) dengarkan bagaimana partner anda menginterpretasi peristiwa yang terjadi. 2) perhatikan informasi yang mungkin diabaikan atau terlalu ditekankan oleh pasangan Anda dalam peristiwa penafsiran 3) dengan jelas menyajikan informasi, pengamatan, dan pendapat yang relevan dan jujur yang memungkinkan pasangan Anda membingkai ulang apa yang telah terjadi. Giving advice, menyajikan saran dan proposal yang relevan yang dapat digunakan seseorang untuk menyelesaikan situasi dengan memuaskan. Terdapat beberapa aturan dalam hal ini, yakni 1) mintalah ijin sebelum memberikan saran, 2) katakan pesan tersebut sebagai salah satu dari banyak saran dengan cara yang dapat ditanggapi oleh penerima 3) menyajikan potensi risiko atau biaya yang terkait jika mengikuti saran 4), menunjukkan bahwa Anda tidak akan tersinggung, seandainya partner Anda memilih untuk mengabaikan rekomendasi Anda atau mencari nasihat lain. Penjelasan-penjelasan di atas mengarah kepada kesimpulan bahwa penelitian ini, bertujuan untuk mengetahui, apakah dukungan komunikasi kelompok memiliki peranan yang sangat penting bagi setiap orang yang mengalami masalah, kesulitan, penderitaan dan lain-lain, yang berada dalam sebuah komunitas. Dalam kasus ini peneliti meneliti tentang, bagaimana Komunikasi kelompok, mendukung ketahanan dari para korban dan keluarga korban Covid-19.

\section{Metode Penelitian}

Penelitian dilakukan dengan pendekatan kualitatif, studi kasus deskriptif, yakni tipe studi kasus yang memulai penelitian dengan melibatkan teori deskriptif. Subjek kemudian diamati dan informasi yang dikumpulkan dibandingkan dengan teori yang sudah ada sebelumnya. (Baxter, Pamela., Jack, M, 2010). Adapun yang menjadi subjek dari penelitian ini adalah keluarga dan penyintas Covid-19, sedangkan yang menjadi objek dari penelitian ini adalah dukungan komunikasi kelompok dalam hal ini fokus kepada supportive message. Untuk menemukan bagaimana dukungan komunikasi kelompok terhadap penyintas dan keluarga penyintas Covid-19, maka penelitian ini melakukan penyelidikan yang mendalam dari berbagai macam informasi mengenai beberapa unit atau kasus untuk satu periode atau antar beberapa periode waktu, dalam kasus ini yakni sejak informan atau juga keluarga mengalami masalah akibat Covid-19 (Newman, 2011). Penelitian studi kasus ini secara intensif menyelidiki satu atau sehimpunan kasus dan konteksnya. Dengan kata lain studi kasus menelaah karakteristik internal setiap kasus dan juga situasi di sekitarnya. Sebagaimana dikemukakan oleh Patton, 1990 dan Yin, 2003, Ciri khas penelitian studi kasus adalah penggunaan berbagai sumber data, sebuah strategi yang juga meningkatkan kredibilitas data. Sumber data potensial dapat mencakup, tetapi tidak terbatas pada: dokumentasi, catatan arsip, wawancara, artefak fisik, tinjauan langsung, dan observasi 
Rose Emmaria Tarigan:

Group Communication Support in Supporting the Resilience of Families and Survivors of Covid19

Dukungan Komunikasi Kelompok Dalam Menunjang Ketahanan Keluarga Dan Penyintas Covid19

partisipan. Dalam penelitian studi kasus, peneliti mengumpulkan dan mengintegrasikan data survei kuantitatif misalnya termasuk dari hasil penelitian terkait Covid-19 yang dilakukan di Wuhan, China, data ini kemudian memfasilitasi pencapaian pemahaman holistik tentang fenomena yang sedang dipelajari. Dalam studi kasus, data dari berbagai sumber ini kemudian digabungkan dalam proses analisis daripada ditangani secara individual. Setiap sumber data adalah satu bagian dari "teka-teki", dengan setiap bagian berkontribusi pada pemahaman peneliti tentang keseluruhan fenomena. Konvergensi ini menambah kekuatan pada temuan, karena berbagai untaian data dijalin bersama untuk mendorong pemahaman yang lebih baik tentang kasus tersebut (Baxter, Pamela., Jack, M, 2010)

Metode pengumpulan data yang digunakan dalam penelitian ini adalah dengan melakukan metode wawancara mendalam (indepth interview), juga observasi lapangan dengan mengamati aktivitas informan sepanjang penelitian berlangsung dilakukan kepada tiga orang informan dengan inisial Y, L dan O, yang merupakan penyintas dan juga keluarga penyintas Covid-19. Data diperoleh lewat wawancara mendalam (indepth interview) dan observasi lapangan akan digunakan sebagai bahan mentah atau row material, untuk dibahas dalam penelitian ini. Penelitian ini juga melakukan validasi konseptual, yakni mengidentifikasi konsep/variable yang menjadi fokus dalam penelitian ini. Sebagai rumusan masalah adalah sebagai berikut "Bagaimana Dukungan Komunikasi Kelompok dalam Menunjang Ketahanan Keluarga dan Penyintas Covid-19”.

\section{Hasil Penemuan dan Diskusi}

Ketiga penyintas Covid 19, yakni Y, L, dan O, juga sebagai keluarga korban mengalami masa-masa yang berat selama dalam proses karantina. Situasi yang serba tidak pasti, karena belum ada obat atau anti virus yang bisa memberikan kepastian menyembuhkan bagi yang positif-Covid 19, sehingga bisa memberi ketenangan batin mereka. Mereka yang sebelumnya berada dalam kondisi sehat, dinyatakan harus menjalani sejumlah tes dan karantina. Selain itu status sebagai ibu, mereka juga harus memikirkan anak-anak mereka yang masih membutuhkan perhatian, karena beberapa di antaranya masih dalam usia sekolah.

\section{Pentingnya Kelompok}

Di tengah kondisi yang mereka alami ini, perhatian dan dukungan dari keluarga dan komunitas atau kelompok di mana mereka aktif berorganisasi seperti gereja dan persekutuan, membuat mereka mendapatkan dukungan yang mereka butuhkan. Antara lain, dukungan memenuhi kebutuhan mereka, seperti; dukungan emosi, moral, informasi, dan juga dukungan jaringan sosial. Terpenuhinya kebutuhan ini, membuat ketiga korban dan keluarga mereka bisa lepas dari tekanan psikologis seperti stres dan depresi, yang sangat mungkin dialami oleh penyintas Covid-19 ini. Dalam hal ini, dukungan komunikasi menjadi sangat fundamental bagi kelompok, khususnya bagi anggota dari sebuah kelompok mengalami masalah, atau kesulitan yang membuat seseorang atau kelompok 
membutuhkan bantuan atau dukungan dari anggota lainnya. Sejumlah penelitian menunjukkan bahwa dukungan dari kelompok menghasilkan dampak yang positif bagi mereka yang didukung. Antara lain, penelitian dari Krause, Liang \& Yatomi, 1989; Lackner et al.,199, bahwa, 1) dukungan yang efektif telah menumbuhkan penyesuaian psikologis dan self efficacy yang artinya, keyakinan seseorang bahwa ia memiliki kemampuan melakukan sesuatu untuk mencapai tujuannya, 2) hasil penelitian dari Pierce, Sarason, \& Sarasons, 1996; Tardy,1994), bahwa dukungan kelompok dapat meningkatkan kemampuan dalam mengatasi masalah yang mengganggu (Burleson R Brant, 2002).

Terbukti dari hasil penelitian yang dilakukan Zhang, kepada sejumlah pasien dengan gejala ringan penyakit Coronavirus-2019 (COVID-19) di Wuhan, Cina, bahwa dukungan sosial menjadi salah satu faktor yang dapat mendukung ketahanan dari penyintas Covid-19 dan keluarga penyintas. Rekomendasi dari temuan tersebut menunjukkan bahwa dukungan sosial atau dukungan komunikasi memberi dampak yang positif kepada, penyintas ataupun keluarganya. Supportive message dalam penelitian ini merupakan bagian dari dukungan sosial atau dukungan komunikasi, menjadi fokus dari penelitian ini. Hasil penelitian ini menunjukkan, bahwa supportive message yang disampaikan oleh kelompok kepada penyintas atau keluarganya memiliki peranan dalam mendukung ketahanan mereka dalam menghadapi masalah yang mereka hadapi. Hasil penelitian seperti sudah dijelaskan di atas membuktikan, bahwa dukungan komunikasi kelompok memiliki peranan penting dalam mendukung ketahanan, baik keluarga penyintas maupun penyintas Covid 19 itu sendiri. Dengan demikian, dukungan kelompok menjadi sangat penting. Menurut Sarwono 2005, kelompok itu memiliki batasan, yakni "dua individu atau lebih yang berinteraksi tatap muka (face to face interaction), yang masing-masing menyadari keanggotaannya dalam kelompok, masing-masing menyadari keberadaan orang lain yang juga anggota kelompok, dan masing-masing menyadari saling ketergantungan secara positif dalam mencapai tujuan yang bersama. Interaksi dalam setiap kelompok menjadi penting karena terbukti kelompok memiliki peranan penting dalam memberi bantuan, penguatan dan juga beragam dukungan lainnya, dan secara spesifik adalah dukungan pesan komunikasi. Sebagaimana dalam penelitian ini, teramati dengan jelas bahwa kelompok memiliki peranan yang sangat besar dalam mendukung ketahanan penyintas dan keluarga penyintas Covid 19, dalam menghadapi dan melewati masa-masa berat ketika mereka diperhadapkan pada musibah tersebut. Penelitian ini fokus kepada dukungan kelompok dalam bentuk support message. Di mana kelompok, memberikan dukungan lewat pesan komunikasinya kepada korban yang digambarkan dalam lima fase, yang memperlihatkan bahwa pesan yang bersifat supportif akan menjadi dukungan yang sangat berarti bagi keluarga dan penyintas Covid 19 .

\section{Support Message}

Hasil penelitian sebagaimana sudah dipaparkan di atas, menunjukkan bahwa support message yang diberikan kelompok seperti diindentifikasi oleh Barbee dan Cunningham (1955), terdiri dari lima fase yang tertata dengan baik, sehingga interaksi yang mendukung tampaknya terus berlanjut, antara lain, Fase 
Rose Emmaria Tarigan:

Group Communication Support in Supporting the Resilience of Families and Survivors of Covid19

Dukungan Komunikasi Kelompok Dalam Menunjang Ketahanan Keluarga Dan Penyintas Covid19

pertama, adalah support activation, fase kedua support provision, fase ketiga target reaction, dan fase empat adalah helper responses. Burlesson mengidentifikasi adanya lima keterampilan, mengemas pesan yang mendukung (support message), antara lain; clarify supportive intentions, buffering face threats, other centered message, framing, giving advice, kelima keterampilan ini akan menjelaskan bagaimana pelaku (anggota kelompok) melakukan dukungan komunikasi terhadap anggota kelompok mereka yang mengalami masalah, musibah atau tekanan. Clarify supportive intentions, artinya bahwa seseorang menyatakan pesan komunikasinya, secara terbuka dan tujuannya dalam percakapan adalah untuk mendukung dan membantu lawan bicaranya. Ketika seseorang berkomunikasi secara terbuka, maka orang lain akan melihat dan bisa merasakan apakah seseorang itu, memiliki agenda tersembunyi atau tidak. Buffering face threats, pelaku komunikasi menggunakan positive facework, yakni berupa pesan yang memproteksi kebutuhan lawan bicara. Ini berbeda dengan negative facework, pesan yang mendukung kebutuhan mitra akan kemandirian dan otonomi secara verbal menggunakan metode tidak langsung ketika menawarkan informasi, pendapat, saran, mereka. Other centered message, mendengarkan secara aktif, mengungkapkan belas kasih dan pengertian, dan mendorong mitra untuk berbicara tentang apa yang telah terjadi, menguraikannya, dan mengeksplorasi perasaan mereka tentang situasi tersebut, Framing, keterampilan memberikan kenyamanan dengan menawarkan informasi, pengamatan, dan pendapat yang memungkinkan pengungkap untuk lebih memahami atau menafsirkan kembali suatu peristiwa atau keadaan, dan yang terakhir, Giving advice, yakni menyajikan saran yang relevan yang dapat digunakan seseorang untuk menyelesaikan situasi dengan memuaskan.

Hasil penelitian ini menunjukkan, bahwa ketiga informan yang berstatus sebagai ibu rumah tangga yakni Ibu Y, Ibu L dan Ibu O memiliki sejumlah kesamaan dalam proses komunikasi kelompok yang mereka hadapi. Dalam kasus ini ketiga orang yang berstatus sebagai ibu ini sama-sama menghadapi situasi sulit, di manas Ibu Y, berstatus ODP juga menghadapi masalah besar pada masa itu, di mana suaminya Pak B, positif Covid 19 yang kemudian menghembuskan nafas, meninggalkan tiga orang anak yang masih membutuhkan perhatiannya. Karena dukungan kelompok yakni yang diberi nama kelompok SPG (supportive Group) dan Gereja, yakni lewat pesan komunikasi yang supportive mereka membuat Ibu Y dan anak-anaknya mampu bertahan dan melewati masa-masa berat ketika Pak B masih hidup dan setelah menghembuskan nafas meninggalkan keluarganya. Terbukti mereka tetap bertahan dan bisa menerima secara lapang dada kepergian Pak B menghadap Tuhan. Demikian juga dengan Ibu L, oleh bantuan dan dukungan kelompok Pasutri atau (pasangan suami istri) yang merupakan kelompok yang sudah didirikan sejak lama, juga oleh jemaat Gereja di mana mereka sekeluarga beribadah telah membantu mereka untuk bisa bertahan menghadapai masa-masa sulit sama seperti keluarga Ibu Y. Tidak jauh berbeda dengan Ibu Y dan Ibu L, Ibu O ternyata juga merasakan bagaimana kelompok yakni Tim Aksi Kasih, dan Gereja telah memberikan mereka dukungan baik materi maupun moril yang dikemas dalam dukungan pesan yang baik telah 
membuat mereka bisa bertahan melewati masa sulit ketika Pak J, suami dari Ibu O dinyatakan harus masuk ruang isolasi hingga dinyatakan pulih kembali.

Penelitian yang dilakukan terhadap ketiga informan ini menunjukkan bahwa mereka berada di lingkungan komunitas atau bergaul dengan kelompok informal yang bukan saja memiliki keyakinan yang sama, tetapi kelompok yang memiliki sikap, perilaku yang sejalan dengan kepercayaannya. Mereka adalah kelompok yang sangat aktif beribadah, aktif melayani, aktif dalam berbagai kegiatan rohani baik di gereja maupun di luar gereja. Selain itu ketiga informan menunjukkan sikap yang positif terhadap musibah yang mereka alami, karena tidak ada dari satu informan pun yang kemudian pasrah, apalagi putus asa dengan menunjukkan sikap yang negatif atas musibah yang mereka alami. Mereka bertiga terlihat tabah, kuat, tetap beryukur bahkan cepat mengalami pemulihan bukan saja fisik tetapi juga secara rohani ataupun secara psikologis. Sikap yang ditunjukkan ketiga informan ternyata pula terlihat memengaruhi reaksi anak-anak mereka, yang tidak ada satupun yang kemudian tertekan dan khawatir secara berlebihan tetapi mereka menjadi lebih anak-anak yang kuat dan siap mnghadapi situasi mereka saat musibah menimpa keluarga mereka.

Selain itu, ketiga informanpun telah mengungkapkan adanya kesamaan dalam pengalaman mereka, bahwa kelompok yang mendukung mereka memiliki kesamaan atau kemiripan dalam kemasan pesan mereka yang cenderung memenuhi kelima fase seperti dikemukakan oleh Burleson dan Albrecht, Goldsmith, \& Sarason, 1994, bahwa, komunikasi "juga layak mendapat tempat yang jauh lebih sentral dalam studi dukungan sosial. Kami percaya bahwa "dukungan sosial harus dipelajari sebagai komunikasi karena pada akhirnya disampaikan melalui pesan yang diarahkan oleh satu orang ke orang lain, dalam konteks hubungan yang dibuat dan dipertahankan melalui interaksi. Komunikasi menjadi sangat penting, khususnya bagaimana pesan dikemas oleh pelaku komunikasi sehingga menjadi komunikasi yang berisi pesan yang supportive bagi yang lain khususnya mereka yang mengalami musibah. Burlesson mengidentifikasi adanya lima keterampilan, mengemas pesan yang mendukung (support message), antara lain; clarify supportive intentions, buffering face threats, other centered message, framing, giving advice, kelima keterampilan ini akan menjelaskan bagaimana pelaku melakukan dukungan komunikasi terhadap anggota kelompok mereka yang mengalami masalah, musibah atau tekanan(Burleson R Brant, 2002).

Hasil penelitian ini menunjukkan bahwa ketiga informan yang berstatus sebagai ibu rumah tangga yakni Ibu Y, Ibu L dan Ibu O memiliki sejumlah kesamaan dalam proses komunikasi kelompok yang mereka hadapi. Dalam kasus ini ketiga orang yang berstatus sebagai ibu ini sama-sama menghadapi situasi sulit, di manas Ibu Y, berstatus ODP juga menghadapi masalah besar pada masa itu, di mana suaminya Pak B, positif Covid 19 yang kemudian menghembuskan nafas, meninggalkan tiga orang anak yang masih membutuhkan perhatiannya. Atas dukungan kelompok, yakni yang diberi nama kelompok SPG (supportive Group) dan Gereja, yakni lewat pesan komunikasi yang supportive mereka membuat Ibu Y dan anak-anaknya mampu bertahan dan melewati masa-masa berat ketika Pak B masih hidup dan setelah menghembuskan nafas meninggalkan 
Rose Emmaria Tarigan:

Group Communication Support in Supporting the Resilience of Families and Survivors of Covid19

Dukungan Komunikasi Kelompok Dalam Menunjang Ketahanan Keluarga Dan Penyintas Covid19

keluarganya. Terbukti mereka tetap bertahan dan bisa menerima secara lapang dada kepergian Pak B menghadap Tuhan. Demikian juga dengan Ibu L, oleh bantuan dan dukungan kelompok Pasutri atau (pasangan suami istri) yang merupakan kelompok yang sudah didirikan sejak lama, juga oleh jemaat Gereja di mana mereka sekeluarga beribadah telah membantu mereka untuk bisa bertahan menghadapai masa-masa sulit sama seperti keluarga Ibu Y. Tidak jauh berbeda dengan Ibu Y dan Ibu L, Ibu O ternyata juga merasakan bagaimana kelompok, yakni Tim Aksi Kasih, dan Gereja telah memberikan mereka dukungan baik materi maupun moril yang dikemas dalam dukungan pesan yang baik telah membuat mereka bisa bertahan melewati masa sulit ketika Pak J, suami dari Ibu O dinyatakan harus masuk ruang isolasi hingga dinyatakan pulih kembali.

\section{Faktor Pendukung Lainnya}

Penelitian yang dilakukan terhadap ketiga informan ini menunjukkan bahwa mereka berada di lingkungan komunitas atau bergaul dengan kelompok yang informal yang bukan saja memiliki keyakinan yang sama, tetapi kelompok yang memiliki sikap, perilaku yang sejalan dengan kepercayaannya. Mereka adalah kelompok yang sangat aktif beribadah, aktif melayani, aktif dalam berbagai kegiatan rohani baik di gereja maupun di luar gereja. Selain itu ketiga informan menunjukkan sikap yang positif terhadap musibah yang mereka alami, karena tidak ada dari satu informan pun yang kemudian pasrah, apalagi putus asa dengan menunjukkan sikap yang negatif atas musibah yang mereka alami. Mereka bertiga terlihat begitu tabah, kuat, tetap bersyukur bahkan cepat mengalami pemulihan bukan saja fisi, tetapi juga secara rohani ataupun secara psikologis. Sikap yang ditunjukkan ketiga informan, menunjukkan mereka memiliki kerpribaian (personality) yang kuat atau tangguh, ternyata memengaruhi reaksi anak-anak mereka, yang pada awalnya sesuai kesaksian informan menunjukkan sikap tertekan (diam, menangis, muram), tetapi dalam perkembangan selanjutnya, tidak ada satupun lagi yang menunjukkan sikap tertekan tersebut, tetapi mereka menjadi lebih kuat dan siap menghadapi situasi mereka saat musibah menimpa keluarga mereka. Ketiga informan ini berhasil melewati masa-masa kritis yang mereka hadapi ketika informan dengan inisial Y, kehilangan suaminya karena positif Covid-19, dan Y sendiri juga positif dan satu dari tiga anaknya turut positif. Demikian halnya dengan D, menjadi istri dari penyintas Covid-19 yang sudah dirawat selama dua bulan lebih dan kemudian dinyatakan sembuh, meskipun anaknya tertua dari tiga bersaudara juga dinyataan positif Covid-19. Informan ketiga adalah dengan inisial L, seorang ibu dari satu anak yang dinyatakan positif Covid-19 dan dirawat selama hampir dua bulan lebih.

\section{Simpulan}

Penelitian yang dilakukan Zhang, kepada sejumlah pasien dengan gejala ringan penyakit Coronavirus-2019 (COVID-19) di Wuhan, Cina, membuktikan bahwa dukungan sosial menjadi salah satu faktor yang dapat mendukung ketahanan dari penyintas Covid-19 dan keluarga penyintas. Rekomendasi dari temuan tersebut menunjukkan bahwa dukungan sosial atau dukungan komunikasi 
memberi dampak yang positif kepada, penyintas ataupun keluarganya. Supportive message dalam penelitian ini merupakan bagian dari dukungan sosial atau dukungan komunikasi, menjadi fokus dari penelitian ini. Hasil penelitian ini menunjukkan, bahwa supportive message yang disampaikan oleh kelompok kepada penyintas atau keluarganya memiliki peranan dalam mendukung ketahanan mereka dalam menghadapi masalah yang mereka hadapi. Dengan perkataan lain, kelompok memiliki peranan penting dalam mendukung anggota kelompok ketika mengalami masalah atau musibah. Sifat dari saling ketergantungan kelompok tentu akan mewujudkan adalah kepedulian kelompok. Support message menjadi salah satu bentuk dukungan kelompok. Burlesson berhasil mengidentifikasi, lima keterampilan mengemas pesan yang mendukung (supportive message), antara lain; clarify supportive intentions, buffering face threats, other centered message, framing, giving advice, kelima keterampilan ini menjelaskan bagaimana pelaku melakukan dukungan komunikasi terhadap anggota kelompok mereka yang mengalami masalah, musibah atau tekanan. Dalam kasus ini adalah masalah yang terkait dengan Covid-19. Keteramilan yang pertama Clarify supportive intentions, di mana seseorang menyatakan pesan komunikasinya, secara terbuka dan tujuannya dalam percakapan adalah untuk mendukung dan membantu penyintas atau keluarganya. Ketika seseorang berkomunikasi secara terbuka, maka orang lain akan melihat dan bisa merasakan apakah seseorang itu, memiliki agenda tersembunyi atau tidak. Buffering face threats, pelaku komunikasi menggunakan positive facework, yakni berupa pesan yang memproteksi kebutuhan lawan bicara. Ini berbeda dengan negative facework, pesan yang mendukung kebutuhan mitra akan kemandirian dan otonomi secara verbal dengan menggunakan metode tidak langsung ketika menawarkan informasi, pendapat, saran, mereka atas masalah yang dihadapi oleh penyintas atau juga keluarganya. Other centered message, mendengarkan secara aktif, mengungkapkan belas kasih dan pengertian, dan mendorong penyintas atau keluarganya, untuk berbicara tentang apa yang telah terjadi, menguraikannya, dan mengeksplorasi perasaan mereka tentang situasi tersebut, Framing, keterampilan memberikan kenyamanan dengan menawarkan informasi, pengamatan, dengan kata lain mampu membingkai pesan yang memberikan kenyamanan kepada penyintas atau keluarga penyintas. Giving advice, yakni menyajikan saran yang relevan yang dapat digunakan penintas atau keluarga penyintas untuk masalah yang mereka sedang hadapi.

Di samping fakta bahwa supportive message telah memberikan dukungan ketahanan kepada penyintas maupun keluarganya, penilitian ini juga menemukan, bahwa kekuatan keyakinan seseorang atau cara pandangnya terhadap masalah atau musibah yang dihadapinya, akan menentukan bagaimana ia bereaksi terhadap masalah tersebut. Dalam penelitian ini, berdasarkan pernyataan dan pengakuan ketiga informan ditemukan bahwa mereka memiliki kesamaan latarbelakang sebagai orang yang aktif beraktivitas di gereja, mereka aktif melayani di komunitas. Mereka juga adalah anggota dari kelompok persekutuan penelahan Alkitab yang telah mereka ikuti sejak lama (belasaan-puluhan tahun). Mereka mengakui bahwa pengenalan mereka akan Tuhan yang mereka percaya, membuat mereka lebih kuat dan tidak pernah meragukan pertolongan Tuhan termasuk 
Rose Emmaria Tarigan:

Group Communication Support in Supporting the Resilience of Families and Survivors of Covid19

Dukungan Komunikasi Kelompok Dalam Menunjang Ketahanan Keluarga Dan Penyintas Covid19

ketika mereka mengalami tekanan yang berat selama mengalami musibah tersebut. Selain itu, penelitian ini juga menemukan bahwa penyintas juga keluarganya, memiliki kepribadian yang kuat, dan mereka berhasil menunjukkan sikap mereka terhadap anak-anak mereka yang pada akhirnya memiliki sikap yang tegar, kuat, tabah seperti sikap yang mereka miliki. Sebagai akibatnya, terbukti ketika salah satu informan menghadapi kematian suaminya akibat Covid-19, dia dan ketiga anak-anaknya mampu menerimanya dan mereka terlihat lebih cepat mengalami pemulihan psikologis. Informan lain yakni Ibu L, masih harus menjalani perawatan intensif karena ditemukan penyakit baru di dalam tubuhnya yang diduga sebagai akibat dari Covid 19 yang pernah menyerang tubuhnya. Namun demikian, Ibu L terlihat lebih kuat dan tabah menerimanya sebagai sesuatu yang tidak akan terjadi tanpa ijin dari Tuhan yang ia percaya.

\section{Ucapan Terimakasih}

Peneliti mengucapkan terimakasih terutama kepada para informan yang menjadi nara sumber dari data yang dibutuhkan bagi penelitian ini. Meskipun masih berduka dan masih dalam perawatan medis pada saat wawancara berlangsung, para informan tetap dengan rela mau memberi waktu bahkan pikiran bahkan mereka siap masuk lagi ke dalam situasi yang menyentuh emosi mereka karena harus flashback lagi ke saat mereka masih berada dalam situasi sakit dan berduka. Peneliti juga berterimakasih kepada Prodi Ilmu Komunikasi Pelita Harapan yang memberikan support sehingga peneliti bisa menyelesaikan penelitian ini.

\section{Daftar Pustaka}

Baxter, Pamela., Jack, M, S. (2010). Qualitative Case Study Methodology: Study Design and Implementation for Novice Researchers. https://doi.org/http://dx.doi.org/10.46743/2160-3715/2008.1573

Burleson R Brant, M. L. E. (2002). Supportive Communication. في Handbook Of Interpersonal Communication (424-374. ص.ص). Sage Publication,Inc.

Felix D, E \& Avivi, W. (2015). The role of social support on mental health following multiple wildfire disasters. Journal of Community Psychology, 156-170. https://doi.org/http://dx.doi.org/10.1002/jcop.21671

Indah, A. (2020). BREAKING NEWS: Tambah 1.624, Jumlah Kasus Virus Corona di Indonesia Jadi 59.394 per 2 Juli 2020 Artikel ini telah tayang di Tribunternate.com dengan judul BREAKING NEWS: Tambah 1.624, Jumlah Kasus Virus Corona di Indonesia Jadi 59.394 per 2 Juli 2020, htt. https://ternate.tribunnews.com/2020/07/02/breaking-news-tambah-1624jumlah-kasus-virus-corona-di-indonesia-jadi-59394-per-2-juli-2020

في .Jones, M, Susane \& Bodie, D, G. (2014). Supportive Communication. Interpersonal Communication (ص ص (20). De Gruyter Mouton.

Macionis, J. (2008). Sociology. Prentice Hall New Jersey. 
Mukaromah, V. (2020). Atasi Corona, Bagaimana Singapura dan Korea Selatan Lakukan Karantina? Artikel ini telah tayang di Kompas.com dengan judul "Atasi Corona, Bagaimana Singapura dan Korea Selatan Lakukan Karantina?" Kompas.Com. https://www.kompas.com/tren/read/2020/03/28/073000565/atasi-coronabagaimana-singapura-dan-korea-selatan-lakukan-karantina-?page=all

Netta, S. (2011). Pengaruh Dukungan Sosial terhadap Motivasi Berprestasi Siswa MAN Jakarta. https://123dok.com/document/6zk831mz-pengaruhdukungan-sosial-terhadap-motivasi-berprestasi-siswa-jakarta.html

Newman, W. L. (2011). Metodologi Penelitian Sosial :Pendekatan Kualitatif dan Kuantitatif, (Edisi Tuju). Pearson Education.Inc Boston.

Sarlito, Wirawan, S. (2005). "Psikologi Sosial, Psikologi Kelompok dan Psikologi Terapan”. Balai Pustaka, Jakarta.

Team, H. E. (2020). COVID-19 Survivors Share How to Recover During Pandemic. https://www.healthline.com/health-news/covid-19-survivorsshare-how-to-recover-during-pandemic $\% 0 \mathrm{~A} \% 0 \mathrm{~A}$

Verderber, S Kathleen; Verderber, F Rudolph; Fink-Berryman, C. (2007). InterAct; Interpersonal Communication Concepts,Skills, and Contexts (Eleventh). Oxford University Press.Inc. http://www.oup.com

Wood, T, J. (2011). Communcation Mosaics; An Introduction to The Field of Communication (M. Eckman (محرر); Sixth Edit). Wadsworth, Cengage Learning.

Zhang, RN Jie, E. a. (د.د). The relationship between resilience, anxiety and depression among patients with mild symptoms of COVID-19 in China: A cross-sectional study. Jurnal of Clinical Nursing, 29(21-22), 4020-4029. https://doi.org/https://doi.org/10.1111/jocn.15425 